\title{
An estimate is worth about a thousand experiments: using order-of-magnitude estimates to identify cellular engineering targets
}

\author{
Kevin James Metcalf $f^{1,3^{*}}$, Marilyn F. Slininger Lee ${ }^{1,4}$, Christopher Matthew Jakobson ${ }^{1,5}$ \\ and Danielle Tullman-Ercek ${ }^{2}$
}

\begin{abstract}
Biotechnological processes use microbes to convert abundant molecules, such as glucose, into high-value products, such as pharmaceuticals, commodity and fine chemicals, and energy. However, from the outset of the development of a new bioprocess, it is difficult to determine the feasibility, expected yields, and targets for engineering. In this review, we describe a methodology that uses rough estimates to assess the feasibility of a process, approximate the expected product titer of a biological system, and identify variables to manipulate in order to achieve the desired performance. This methodology uses estimates from literature and biological intuition, and can be applied in the early stages of a project to help plan future engineering. We highlight recent literature examples, as well as two case studies from our own work, to demonstrate the use and power of rough estimates. Describing and predicting biological function using estimates guides the research and development phase of new bioprocesses and is a useful first step to understand and build a new microbial factory.
\end{abstract}

Keywords: Bioprocess, Synthetic biology, Metabolic engineering

\section{Background}

Every microbial production process begins with an exciting but daunting set of problems-we want to know if the process is feasible, and how to increase production of a complex biological system or pathway when the best approach may be non-obvious. These problems are particularly difficult if the system or pathway in question has never been used in an engineering context before. In the following review, we outline the methodology our group developed to inform these decisions. We combine simple biological and biochemical observations [1] with intuitive estimates to identify the aspects of the biological system that will have the greatest impact on product yield

\footnotetext{
*Correspondence: kevin.metcalf@northwestern.edu;

kevin.metcalf2@gmail.com

${ }^{1}$ Department of Chemical and Biomolecular Engineering, University

of California, Berkeley, CA 94720, USA

Full list of author information is available at the end of the article
}

to guide engineering efforts (Fig. 1). Many approximate values come from the BioNumbers database [2], and we cite the BioNumber identification number (BNID), where applicable. We also use significant figures in the estimates to signify the degree of precision in an estimate, following rules outlined in the text Cell Biology by the Numbers [3]. Simultaneously, we identify other aspects of a system that are unlikely to significantly impact our targets, in order to exclude these from our engineering efforts. This exercise is a useful addition to the planning stages of any biological engineering endeavor. Below, we discuss examples from the literature, and we use case studies from our work to outline the molecular-level estimates of achievable cellular behaviors. At the end, we describe a decision scheme for applying rough estimates to a new bioprocess. We encourage others in the field to include their rough estimates for process feasibility and engineering targets in their published work. 


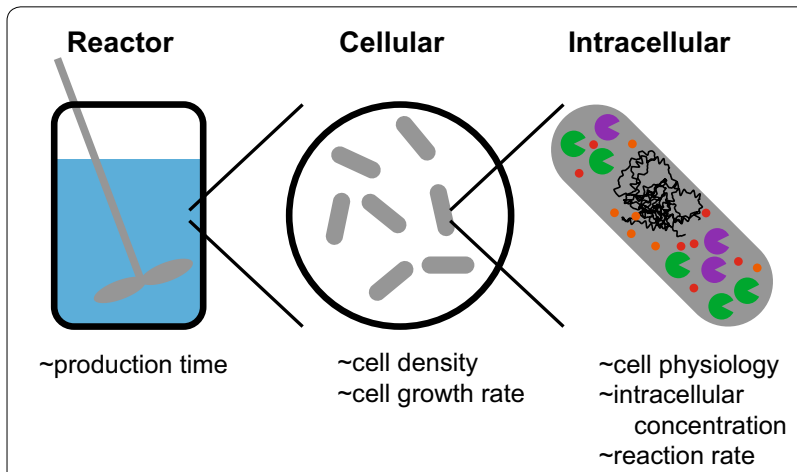

Fig. 1 Order-of-magnitude estimates are made across different scales of a bioprocess

Table 1 Turnover number $\left(\boldsymbol{k}_{\text {cat }}\right)$ for enzymes with published kinetic data used in the artemisinic acid pathway in S. cerevisiae [8]

\begin{tabular}{lll}
\hline Enzyme & $\boldsymbol{k}_{\text {cat }}\left(\mathbf{s}^{\mathbf{- 1}}\right)$ & Reference \\
\hline ERG10 & NR & \\
ERG13 & NR & \\
tHMG1 & $0.4^{\mathrm{a}}$ & {$[9]$} \\
ERG12 & 16 & {$[10]$} \\
ERG8 & $40^{\mathrm{a}}$ & {$[11]$} \\
MVD1 & 5 & {$[12]$} \\
IDI1 & $7^{\mathrm{a}}$ & {$[13]$} \\
ERG20 & $\mathrm{NR}$ & \\
ADS & 0.2 & {$[6]$} \\
CYP71AV1/CPR1/CYB5 & $\mathrm{NR}$ & \\
ADH1 & 41 & {$[5]$} \\
ALDH1 & 1.5 & {$[14]$} \\
\hline
\end{tabular}

NR not reported

${ }^{a}$ Estimated from specific activity

\section{Estimates for production of artemisinin}

Rough estimates help to characterize complex biological systems and improve product yield. In a landmark study, Keasling and coworkers used Saccharomyces cerevisiae to produce artemisinic acid, a precursor to the antimalarial drug artemisinin [4]. After an economic analysis of the process, they targeted a titer of $25 \mathrm{~g} / \mathrm{L}$ in production, a feat they recently achieved [5]. We show a rough estimate to justify, in retrospect, this effort. The enzyme amorphadiene synthase (ADS) from Artemisia annua catalyzes the cyclization of farnesyl diphosphate to amorpha-4,11-diene a turnover number of $0.2 \mathrm{~s}^{-1}$ [6], which is relatively slow compared to the other enzymes in the pathway [7] (Table 1).

We therefore assume that this enzyme is substrate-saturated and catalyzes the rate-determining reaction step. Using BioNumbers estimates for S. cerevisiae, as well as experimental values from their recent publication [5], we estimate that this process can yield up to $16 \mathrm{~g} / \mathrm{L}$ artemisinic acid (calculation 1).

Estimated maximum titer of artemisinic acid in S. cerevisiae (BNIDs 104150 and 100986)

$$
\begin{aligned}
& \left(1.3 \times 10^{6} \frac{\mathrm{ADS}}{\text { cell }}\right)\left(\frac{1 \text { mole ADS }}{6.02 \times 10^{23} \text { molecules ADS }}\right) \\
& \times(15 \mathrm{OD})\left(\frac{3 \times 10^{7} \text { cells }}{\mathrm{OD} \times \mathrm{mL}}\right)\left(0.2 \mathrm{~s}^{-1}\right)\left(\frac{60^{2} \mathrm{~s}}{1 \mathrm{~h}}\right) \\
& \times(100 \mathrm{~h})\left(\frac{10^{3} \mathrm{~mL}}{1 \mathrm{~L}}\right)\left(\frac{234 \mathrm{~g}}{\mathrm{~mol}}\right) \approx 16 \frac{\mathrm{g}}{\mathrm{L}}
\end{aligned}
$$

This estimate assumes that ADS has an abundance of $1.3 \times 10^{6}$ enzymes per cell, which is the upper limit of native protein copies in a yeast cell (BNID 104150). This expression level is $\sim 3 \%$ of the total protein (BNID 110550), and overexpression to $2 \times 10^{6} \mathrm{ADS} /$ cell would result in the target titer of $25 \mathrm{~g} / \mathrm{L}$. This analysis gives us an intuition for the bioprocess and serves as a benchmark for the physical limitations of this cellular process. Further increases to the product titer could be achieved by increasing the cell density, culture time, and reaction rate of ADS. A limitation of the analysis presented here is that the rate-determining enzyme must be known, and its kinetic parameters measured or estimated. When faced with a poorly defined set of enzymes, there is no substitute for intuition and accurate guesses of enzyme activity. To aid in assessing processes with limited kinetic information a lower bound for $k_{\text {cat }}$ of $0.1 \mathrm{~s}^{-1}$ captures the large majority of known activities [15].

\section{Estimates for production of electrical energy}

This type of analysis is not limited to the production of molecules-microbial production of high-energy electrons is also amenable to analysis using rough estimates. For example, in a microbial fuel cell, bacteria are used as a catalyst to convert carbon-based chemical energy to electrical energy. Chaudhuri and Lovley [16] showed that the rate of metabolism, efficiency of electron transfer, and microbial density on the electrode are determining factors for predicting the current density of a microbial fuel cell. In order to improve fuel cell performance, which parameter should an engineer first modify? The authors used a straightforward calculation to determine that electron transfer efficiency is already quite efficient-the bacterium Rhodoferax ferrireducens achieved a yield of 740 coulombs (C) of the theoretical limit of $900 \mathrm{C}$ that can be extracted by the complete oxidation of the $0.39 \mathrm{mmol}$ of glucose fed. On the other hand, they found that current density is improved by selecting appropriate electrode 
materials. Interestingly, the authors observed a twofold increase in current density with a new anode material, which correlated with a twofold increase in microbial density on the electrode. Using the authors' measurement of $0.086 \mathrm{mg}$ protein $/ \mathrm{cm}^{2}$, we estimate this new material resulted in $6 \times 10^{8}$ cells $/ \mathrm{cm}^{2}$ cell density on the anode (calculation 2).

\section{Experimental cell density on anode (BNIDs 109352} and 103904)

$$
\begin{aligned}
& \left(\frac{0.086 \mathrm{mg} \text { protein }}{\mathrm{cm}^{2}}\right)\left(\frac{2 \mathrm{mg} \text { DCW }}{\mathrm{mg} \text { protein }}\right)\left(\frac{\text { cell }}{280 \mathrm{fg}}\right)\left(\frac{10^{12 \mathrm{fg}}}{1 \mathrm{mg}}\right) \\
& \approx 6 \times 10^{8} \frac{\mathrm{cells}}{\mathrm{cm}^{2}}
\end{aligned}
$$

Assuming that $\sim 1 / 6$ of the $6 \mu \mathrm{m}^{2}$ bacterial surface area (BNID 101792) is in contact with the electrode, we estimate up to $1 \times 10^{8}$ cells $/ \mathrm{cm}^{2}$ could be attached to the anode (calculation 3 ).

\section{Maximum cell density on anode}

$$
\left(\frac{\text { cell }}{1 \mu \mathrm{m}^{2}}\right)\left(\frac{\left(10^{6}\right)^{2} \mu \mathrm{m}^{2}}{\left(10^{2}\right)^{2} \mathrm{~cm}^{2}}\right) \approx 1 \times 10^{8} \frac{\text { cells }}{\mathrm{cm}^{2}}
$$

This theoretical estimate is within one order of magnitude of the experimental estimate and suggests that the current density cannot be improved by increasing microbial density on the anode, as the anode surface is likely already saturated with bacteria. Further improvements to this system may also focus on the rate of metabolism of the bacterial cell. We support this claim using values estimated for Escherichia coli, which is similar in size and shape to $R$. ferrireducens [17]. E. coli can take up $12 \mathrm{mmol}$ glucose/g dry cell weight (DCW)/h (BNID 109686) [18]. Such uptake could yield a current density of $1 \mathrm{~mA} / \mathrm{cm}^{2}$, over two orders of magnitude greater than the observed $7.4 \times 10^{-3} \mathrm{~mA} / \mathrm{cm}^{2}$, assuming a similar cellular attachment density (calculation 4).

\section{Current density at maximum glucose uptake (BNIDs 109686 and 109352)}

$$
\begin{aligned}
& \left(12 \frac{\mathrm{mmol} \text { glucose }}{\mathrm{g} \mathrm{DCW} \times \mathrm{h}}\right)\left(\frac{\mathrm{g} \mathrm{DCW}}{10^{3} \mathrm{mg} \mathrm{DCW}}\right)\left(\frac{2 \mathrm{mg} \mathrm{DCW}}{\mathrm{mg} \text { protein }}\right) \\
& \quad \times\left(\frac{0.086 \mathrm{mg} \text { protein }}{\mathrm{cm}^{2}}\right)\left(\frac{1 \mathrm{~h}}{60^{2} \mathrm{~s}}\right)\left(\frac{24 \mathrm{mmol} e^{-}}{1 \mathrm{mmol} \text { glucose }}\right) \\
& \quad \times\left(\frac{9.65 \times 10^{4} \mathrm{mC}}{1 \mathrm{mmol} e^{-}}\right)\left(\frac{\mathrm{C}}{10^{3} \mathrm{mC}}\right) \approx 1 \frac{\mathrm{mA}}{\mathrm{cm}^{2}}
\end{aligned}
$$

Clearly, future improvements to this system should focus on increasing metabolic flux. In a related study, Nocera and colleagues showed how rough estimates can be used to improve the design of bioelectrochemical cells for fuel production from sunlight. Here, increased bacterial viability and a redesigned apparatus were offered by the authors as future system improvements [19]. Indeed, in a recent paper, the authors show how a redesigned electrode catalyst increases bacterial viability and improves efficiency of biofuel production by over 20-fold [20]. Together, these examples reveal how rough estimates of cell metabolism and physiology provide important insight into improving a bioprocess.

\section{Case study 1: evaluation of the capacity of a protein secretion system}

Many bioprocesses take advantage of existing, natural biological functions that are engineered with a top-down approach to improve function in the bioreactor environment. For such systems, estimates evaluate native function and guide experiments to modify the system for improved performance. In the following example, we describe how a protein secretion apparatus might be modified for increased protein production. Our targets are difficultto-produce heterologous proteins. Engineering bacteria to secrete the protein product to the extracellular space is expected to improve production of these toxic or hard-topurify proteins [21]. To achieve this activity, we adapted the type III secretion system of Salmonella enterica. When we started working on this problem, we used estimates to answer three key questions:

1. Can secretion improve the production of proteins with toxic effects?

2. What is the native capacity of the secretion system?

3. If the native capacity is below the desired production level, how should the secretion system be manipulated to achieve increased protein yield?

First, we predict the steady-state intracellular concentration of the toxic protein of interest. Cellular fitness may be increased if the rate of protein secretion is matched with the rate of protein production, such that a low intracellular concentration of the toxic protein is maintained at steady-state, while the toxic protein accumulates in the extracellular space. As an example, we consider that a $50 \mathrm{kDa}$ protein of interest is produced by the ribosomes at a rate of up to $10^{3}$ proteins/s/cell (calculation 5). 


\section{Maximal translation rate per cell (BNIDs 100059} and 101441)

$$
\begin{aligned}
& \left(10^{1} \frac{\text { amino acids }}{\mathrm{s} \times \text { ribosome }}\right)\left(\frac{1 \text { protein }}{450 \text { amino acids }}\right) \\
& \times\left(10^{4}-10^{5} \frac{\text { ribosomes }}{\text { cell }}\right) \approx 10^{2}-10^{3} \frac{\text { proteins }}{\mathrm{s} \times \text { cell }}
\end{aligned}
$$

Note that in this example, we assume that all ribosomes are actively translating the protein of interest. We also estimate the secretion rate per cell from the type III secretion system using known parameters [1, 22]. Proteins are secreted at a rate of $10^{3}-10^{4}$ amino acids per second per apparatus $[23,24]$, and each cell has $10^{1}-10^{2}$ secretion apparatus per cell [25]. Therefore we estimate a secretion rate of $10^{1}-10^{3}$ proteins per second per cell for a $50 \mathrm{kDa}$ protein (calculation 6) (Fig. 2a).

\section{Maximal secretion rate per cell}

$$
\begin{gathered}
\left(10^{3}-10^{4} \frac{\text { amino acids }}{\mathrm{s} \times \text { apparatus }}\right)\left(10^{1}-10^{2} \frac{\text { apparatus }}{\text { cell }}\right) \\
\times\left(\frac{1 \text { protein }}{450 \text { amino acids }}\right) \approx 10^{1}-10^{3} \frac{\text { proteins }}{\mathrm{s} \times \text { cell }}
\end{gathered}
$$

Our estimate of the maximal secretion rate is on the same order of magnitude as the maximal translation rate. This suggests that a low intracellular concentration of protein can be maintained by controlling the rate of translation to match the rate of secretion [26]. Thus, we expect that increased production of a toxic protein can be achieved by mitigating cytotoxic effects through maintaining a low steady-state intracellular concentration.

Now we address the second question: What is the capacity of the native protein secretion system? We desire a product titer of $10 \mathrm{~g} / \mathrm{L}$ in a $72 \mathrm{~h}$ batch in order to compete with current industry performance $[27,28]$. We estimate the secreted titer by integrating the estimated secretion rate per cell across all cells in the culture. Cultures reach an optical density of $\sim 1 \mathrm{OD}$, equivalent to about $10^{9}$ cells/mL (BNID 104831) [29]. Only 30\% of cells secrete product in this environment $[30,31]$, such that the predicted secreted protein titer of a $50 \mathrm{kDa}$ protein is $10^{1}-10^{3} \mathrm{mg} / \mathrm{L}$ in an $8 \mathrm{~h}$ batch (calculation 7) (Fig. 2b).

\section{Native production capacity (BNID 104831)}

$$
\text { (8 } \begin{aligned}
\text { h) } & \left(\frac{60^{2} \mathrm{~s}}{1 \mathrm{~h}}\right)\left(10^{3}-10^{4} \frac{\text { amino acids }}{\mathrm{s} \times \text { apparatus }}\right) \\
\times & \left(10^{1}-10^{2} \frac{\text { apparatus }}{\text { cell }}\right)\left(10^{9} \frac{\text { cells }}{\mathrm{mL}}\right) \\
& \times\left(\frac{0.3 \text { secretion - active cells }}{1 \text { total cells }}\right)\left(\frac{1 \text { protein }}{450 \text { amino acids }}\right) \\
& \times\left(\frac{1 \text { mole protein }}{6.02 \times 10^{23} \text { proteins }}\right)\left(\frac{50 \times 10^{3} \text { g protein }}{1 \text { mole protein }}\right) \\
& \times\left(\frac{10^{3} \mathrm{~mL}}{1 \mathrm{~L}}\right)\left(\frac{10^{3} \mathrm{mg}}{1 \mathrm{~g}}\right) \approx 10^{1}-10^{3} \frac{\mathrm{mg}}{\mathrm{L}}
\end{aligned}
$$

This range of values agrees well with published titers of $\sim 10 \mathrm{mg} / \mathrm{L}$ from an $8 \mathrm{~h}$ batch [32], supporting the validity of our analysis and suggesting that some of the parameters used in our analysis may be overestimated. This estimate also corresponds to a titer of $10^{-1}-10^{1} \mathrm{~g} / \mathrm{L}$ in a $72 \mathrm{~h}$ batch. This analysis reveals that our engineering goal of $10 \mathrm{~g} / \mathrm{L}$ secreted protein might be achieved by optimizing the native secretion capacity of the type III secretion system, and identifies five parameters that contribute to secreted protein titer:

1. Fraction of cells that are secretion-active.

2. Culture density.

3. Number of apparatus per cell.

4. Secretion rate.

5. Culture time with which proteins are secreted.

This list helps us address our third question-we can now identify parameters to manipulate to achieve the target titer of $10 \mathrm{~g} / \mathrm{L}$. An increase in any of the five parameters will result in a proportional change in the product titer. Some parameters, such as culture density [33] or the fraction of cells that are secretion-active [30], can be easily manipulated. Improving the culturing conditions for high cell density culture, while maintaining secretion activity, will cause a concomitant increase in secreted protein titer. Further, the secretion activity on a per cell basis can be manipulated using transcriptional control to increase expression of type III secretion system genes [23]. Other parameters are harder to manipulate experimentally due to physiological limits. For example, if we 
a Secretion rate per cell

$$
\left(10^{3}-10^{4} \frac{\text { amino acids }}{\mathrm{s} \cdot \text { apparatus }}\right) \times\left(10^{1}-10^{2} \frac{\text { apparatus }}{\text { cell }}\right) \times\left(\frac{1}{450} \frac{\text { protein }}{\text { amino acids }}\right) \approx 10^{2}-10^{3} \frac{\text { protein }}{\text { cell.s }}
$$

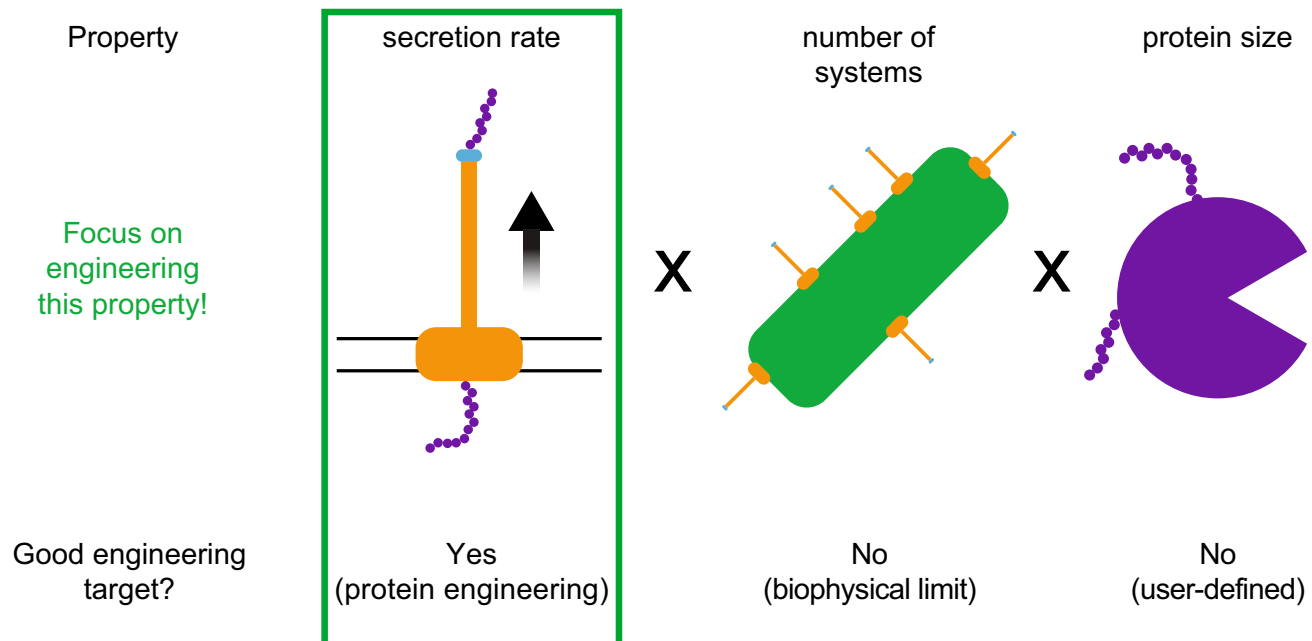

b Secreted protein titer per culture volume

$10^{2}-10^{3} \frac{\text { protein }}{\text { cell } \cdot \mathrm{s}} \quad \times\left(0.3 \frac{\text { secretion-active }}{\text { cell }}\right) \quad x \quad\left(10^{9} \frac{\text { cells }}{\mathrm{mL}}\right) \quad \times \quad$...unit conversions... $\approx 10^{1}-10^{3} \frac{\mathrm{mg} \text { protein }}{\mathrm{L}}$

From (a)

Property engineering these properties!

Good engineering target?
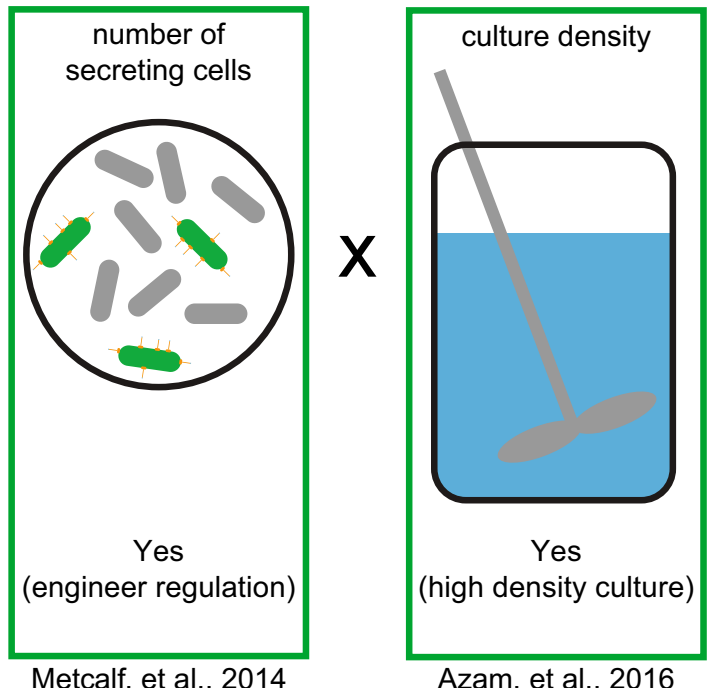

Fig. 2 Diagram of estimates used to predict performance of a bacterial protein secretion system. a Estimate of per cell protein secretion rate. $\mathbf{b}$ Estimate of secreted protein titer

approximate a cross-sectional area of $1000 \mathrm{~nm}^{2} /$ apparatus [25], the average $S$. enterica cell $\left(6 \mu \mathrm{m}^{2}\right.$, BNID 103711) experiences $0.1-1 \%$ of the inner membrane surface area occupied by type III secretion system apparatus (calculation 8). 
Surface area occupied by secretion system apparatus (BNID 103711)

$$
\begin{aligned}
& \frac{\text { surface area of apparatus }}{\text { cellular surface area }}=\left(1000 \frac{\mathrm{nm}^{2}}{\text { apparatus }}\right) \\
& \times\left(\frac{1 \mu \mathrm{m}^{2}}{\left(10^{3}\right)^{2} \mathrm{~nm}^{2}}\right)\left(10-100 \frac{\text { apparatus }}{\text { cell }}\right)=0.1-1 \%
\end{aligned}
$$

If the number of apparatus were increased to $10^{3}$ per cell, this would increase the fraction of the inner membrane occupied by the type III secretion apparatus to $10 \%$, likely decreasing cell viability, as this is a very high fraction of the membrane to devote to a large structure that spans both the inner and outer membrane. Thus, attempting to manipulate this variable would not likely be fruitful in achieving the desired process goal.

In our work, we controlled expression of the secretion system to increase the fraction of cells that are secretionactive by $\sim$ threefold and enable a $\sim$ threefold increase in culture density. By introducing transcriptional control, we manipulate these two key variables simultaneously and achieve $\mathrm{a} \sim$ tenfold increase in secreted protein titer [34]. Engineering improvements that were identified by rough estimates resulted in a bacterial strain that was able to produce and secrete heterologous proteins at high titer and enabled the production of difficult-to-express repetitive proteins [35]. We expect increased product titer by further manipulation of the five aforementioned variables. With a goal of $10 \mathrm{~g} / \mathrm{L}$ in $72 \mathrm{~h}$, we expect that a fivefold further increase in culture density will achieve the target titer of secreted proteins.

\section{Case study 2: feasibility of enzyme pathway compartmentalization}

Estimates can also be used to understand the physical limits of cellular properties and thus establish the upper limit on production of a desired product. Here, we consider the design of subcellular nanoreactors based on naturally occurring organelles. Subcellular structures, such as the carboxysome and the mitochondrion, are spatially and chemically segregated from the rest of the cell to create a specialized metabolic environment [36]. Inspired by these examples from Nature, a subcellular compartment optimized for production of a desired molecule could increase titer, as bioproduction and metabolic homeostasis are decoupled through spatial separation.
Towards this goal, our group has sought to repurpose the native bacterial microcompartment (MCP) complex of $S$. enterica for metabolic engineering of diverse bioproducts. When we began this project, we first asked, "Can MCPs be used in the production of an industrially relevant compound at sufficient titer?" Again, we obtain an order-of-magnitude estimate of physical requirements for a desired product yield using rough estimates of the relevant parameters.

We calculate the feasibility of a desired titer from the amount of enzyme that can physically fit within the MCP compartment volume. We note that the MCP is approximately spherical, with a diameter of $\sim 100 \mathrm{~nm}$, and that the maximum number of MCPs per cell is likely to be around $100[37,38]$, such that up to $1-10 \%$ of the cell volume is occupied by MCPs. At a culture density of 1 OD, MCPs represent $0.005 \%$ of the culture volume (calculation 9) (Fig. 3a).

\section{Culture volume fraction of microcompartments (BNID 104831)}

$$
\begin{aligned}
& \left(\frac{\frac{4}{3} \pi(50 \mathrm{~nm})^{3}}{\mathrm{MCP}}\right)\left(100 \frac{\mathrm{MCP}}{\text { cell }}\right)\left(\frac{10^{9} \text { cells }}{\mathrm{mL}}\right)\left(\frac{\mathrm{mL}}{\left(10^{7}\right)^{3} \mathrm{~nm}^{3}}\right) \\
& \quad \times 100 \approx 0.005 \%
\end{aligned}
$$

From this calculation, it is clear that the fractional volume of MCPs in a culture is most significantly determined by the culture density. Does the estimated MCP volume afford enough space for enzymes inside the MCP to produce industrially relevant amounts of a compound of interest? Commodity chemicals are typically produced at concentrations of $50-150 \mathrm{~g} / \mathrm{L}$ after $48 \mathrm{~h}$ of fermentation, and desired titers are dictated by process economics $[39,40]$. For this estimate, we set a target of $50 \mathrm{~g} / \mathrm{L}$ in $48 \mathrm{~h}$ of the commodity product 1,2-propanediol (1,2-PD). We calculate the quantity needed of the enzyme with the lowest $k_{\text {cat }}$ from the 1,2-propanediol production pathway, GldA (Table 2), under substrate saturating conditions to see if this target is physically possible. The specific activity of GldA has been experimentally determined to be $5 \mu \mathrm{mol} 1,2-\mathrm{PD} / \mathrm{min} / \mathrm{mg}$ GldA at saturation [41]. Assuming saturation of GldA, we calculate the minimum concentration of GldA required to achieve this product titer is $50 \mathrm{mg} / \mathrm{L}$ (calculation 10) (Fig. 3b). 
a MCP volume fraction in culture

$$
\left(4 / 3 \cdot \pi \cdot 50^{3} \frac{\mathrm{nm}^{3}}{\mathrm{MCP}}\right) \quad \mathrm{x} \quad\left(10^{2} \frac{\mathrm{MCP}}{\text { cell }}\right) \quad x \quad\left(10^{9} \frac{\text { cells }}{\mathrm{mL}}\right) \quad x \ldots \approx 0.005 \%
$$

Property

Focus on engineering this property!

Good engineering target?

No

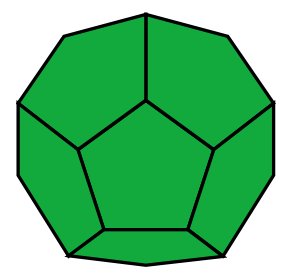

(unknown mechanism)

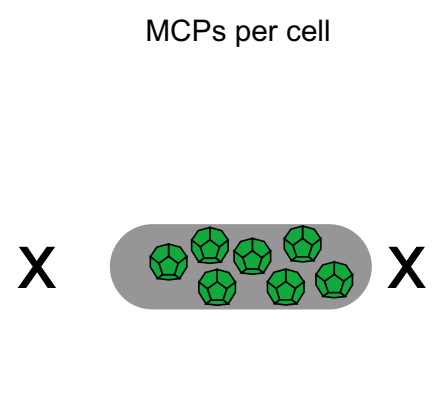

No

(biophysical limit) culture density

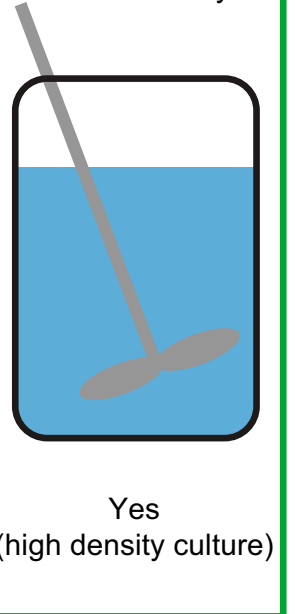

Kim, et al., 2014

b $\underline{\text { Required enzyme concentration for desired product titer }}$
$\left(1 \frac{\mathrm{g} 1,2 \mathrm{PD}}{\mathrm{L} \text { culture }}\right) \times\left(\frac{1 \mathrm{~mol}}{76 \mathrm{~g}}\right) \times\left(\frac{K_{\mathrm{M}}+[\mathrm{S}]}{[\mathrm{S}]}\right)$
$x \quad\left(\frac{1}{9} \frac{\mathrm{mg} \cdot \mathrm{min}}{\mu \mathrm{mol}}\right) \times$
...unit conversions... $\approx 1 \frac{\mathrm{mg} \text { enzyme }}{\mathrm{L} \text { culture }}$

Property

Focus on

engineering

these properties!

Good engineering target?
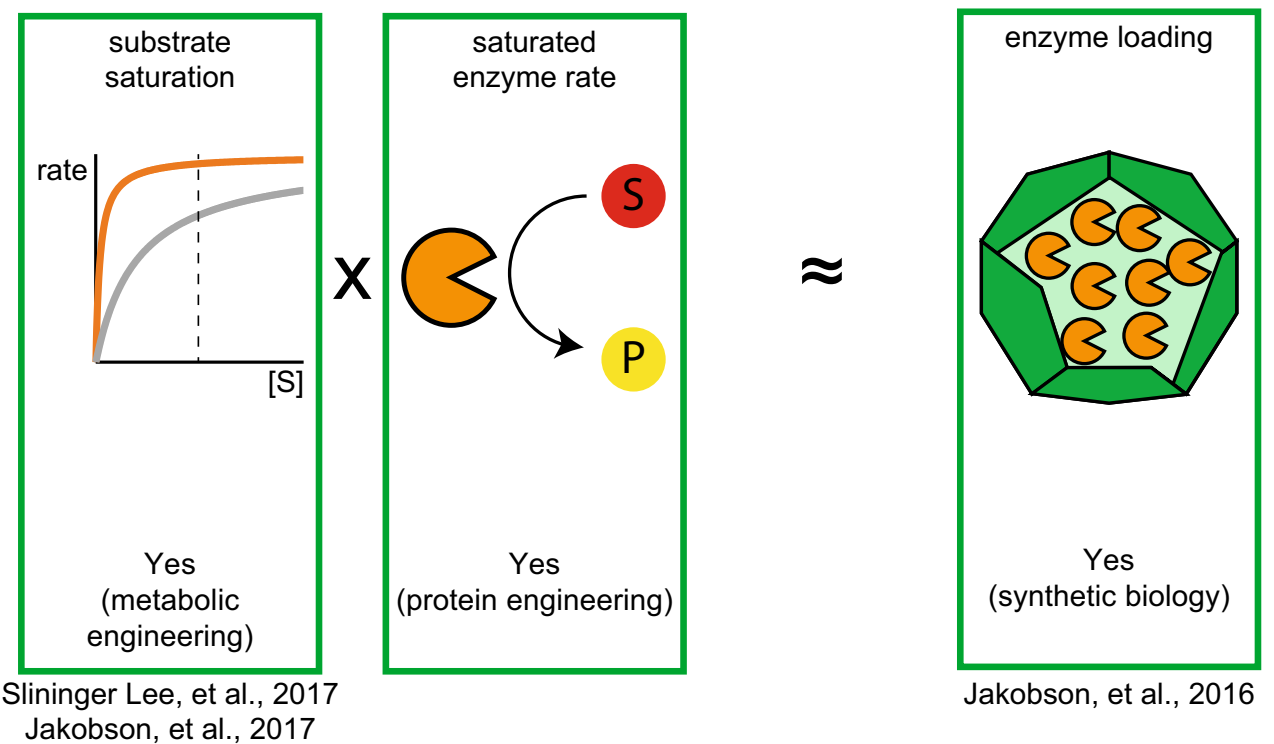

Jakobson, et al., 2016

Fig. 3 Diagram of estimates used to predict physical requirements to encapsulate a metabolic pathway in bacterial microcompartments. a Estimate of fraction of culture volume occupied by microcompartments. $\mathbf{b}$ Estimate of enzyme concentration required for a desired product yield 


\begin{tabular}{lcc}
$\begin{array}{l}\text { Table } 2 \text { Turnover } \\
\text { in the 1,2-propanediol pathway [41] }\end{array}$ & for & enzymes \\
\hline Enzyme & $\left.\boldsymbol{k}_{\text {cat }} \mathbf{( s}^{-\mathbf{1}}\right)$ & Reference(s) \\
\hline MgsA & 220 & {$[42]$} \\
AKR & 30 & {$[43]$} \\
GldA & $0.4^{\mathrm{a}}$ & {$[41]$} \\
\hline
\end{tabular}

$N R$ not reported

${ }^{\text {a }}$ Estimated from specific activity

\section{Concentration of rate-determining enzyme to achieve} desired product titer

$$
\begin{aligned}
& \left(50 \frac{\mathrm{g} 1,2-\mathrm{PD}}{\mathrm{L} \text { culture }}\right)\left(\frac{1 \mu \mathrm{mol} 1,2-\mathrm{PD}}{76 \mu \mathrm{g} 1,2-\mathrm{PD}}\right)\left(\frac{\mathrm{min} \cdot \mathrm{mg} \mathrm{GldA}}{5 \mu \mathrm{mol} 1,2-\mathrm{PD}}\right) \\
& \times\left(\frac{10^{6} \mu \mathrm{g}}{1 \mathrm{~g}}\right)\left(\frac{1 \mathrm{~h}}{60 \mathrm{~min}}\right)\left(\frac{1}{48 \mathrm{~h}}\right)=50 \frac{\mathrm{mg} \mathrm{GldA}}{\text { L culture }}
\end{aligned}
$$

Does this concentration of enzyme physically fit inside the MCPs? The approximate density of the GldA enzyme was calculated from the amino acid sequence using the Northwestern peptide properties calculator [44]. The volume of the GldA protein molecule is $5 \times 10^{4} \AA^{3}$ and the molecular weight is $40 \times 10^{3} \mathrm{~g} / \mathrm{mol}$, giving a density of $1.4 \mathrm{~g} / \mathrm{cm}^{3}$. We then calculate the volume fraction of GldA in MCPs required for our desired product titer (calculation 11).

\section{Fraction of MCP required for GldA}

$$
\begin{aligned}
& \frac{\left(\frac{50 \text { mg enzyme }}{\text { L culture }}\right)\left(\frac{\mathrm{cm}^{3} \text { enzyme }}{1.4 \text { g enzyme }}\right)\left(\frac{\mathrm{g}}{10^{3} \mathrm{mg}}\right)\left(\frac{\mathrm{L}}{10^{3} \mathrm{~cm}^{3}}\right)}{\frac{0.00005 \mathrm{~L} \mathrm{MCP}}{\mathrm{Lculture}}} \\
& \approx 0.7 \frac{\mathrm{L} \mathrm{enzyme}}{\mathrm{L} \mathrm{MCP}}
\end{aligned}
$$

To produce the desired titer, $70 \%$ of the MCP volume must be occupied by GldA. While this fractional loading is high, is shows that the process is feasible and that modest improvements to the process would improve titer. For example, if the cell density was increased to $10 \mathrm{OD}$, only $7 \%$ of the MCP volume would need to be occupied by GldA. This fractional loading of the rate-determining enzyme suggests that MCPs are large enough to fit multiple enzymes in a pathway. The rest of the MCP volume is available for other enzymes in the pathway, as well as metabolites.

The variables we found to affect this calculation are the:

1. Size of MCPs per cell.

2. Number of MCPs per cell.

3. Saturation of the encapsulated enzymes by cognate substrates.

4. Loading of enzymes within the MCP.
5. Maximum reaction rates of the loaded enzymes.

6. Culture density.

Of these variables, the saturation of encapsulated enzymes, loading of enzymes within the shell, and improved culture density all make attractive targets. For the 1,2-PD example, we assumed saturation of the enzyme and an enzyme loading of $70 \%$. Saturation is a feature that depends on culture conditions and shell permeability, as well as on the kinetic constants of the pathway enzymes, and the impact of engineering enzyme turnover and saturation will vary depending on the system [45]. Further, if we consider enzyme engineering to increase the specific activity, we would expect a concomitant increase in product titer, though this is often not trivial. Thus, to increase product titer tenfold, we predict that increasing culture density to 10 OD would suffice. Changing the size or number of MCPs is a much more challenging target, as the mechanisms controlling these phenotypes are unknown, and would not improve titers by orders of magnitude.

Therefore, in our work we first set out to improve control over MCP expression, the permeability of the MCP shell, and enzyme loading. Controlling expression of MCP genes enables increased culture density [46]. Further, controlling permeability of the protein shell to metabolites changes the concentration of substrates in the MCP [45, 47], enabling operation at substrate-saturating regimes. Finally, the loading of enzymes in the MCP can be modulated via the targeting sequence and expression levels [48], and the low fractional volume of enzymes in MCPs enables modulation of enzyme loading. If further improvements are needed, increasing the specific activity of the enzyme-by engineering or identifying more active homologs - might be the next best target because it could improve yield by an additional one or more orders of magnitude.

\section{Using rough estimates in new bioprocesses}

The above examples highlight the value of the rough estimates in successful bioprocess engineering projects. At the project outset, estimates help to determine if the process is feasible. Further along in the project, estimates identify properties to improve. In all cases, successful use of estimates will require a keen biological intuition. To help build an intuition, we encourage others working in this area to use a decision scheme (Fig. 4) to guide their process analysis and engineering efforts, and emphasize that moving through this scheme requires balancing the potential payoff with the amount of effort it will require. Moreover, we expect that the majority of successful projects used such a decision scheme, yet few have discussed their 


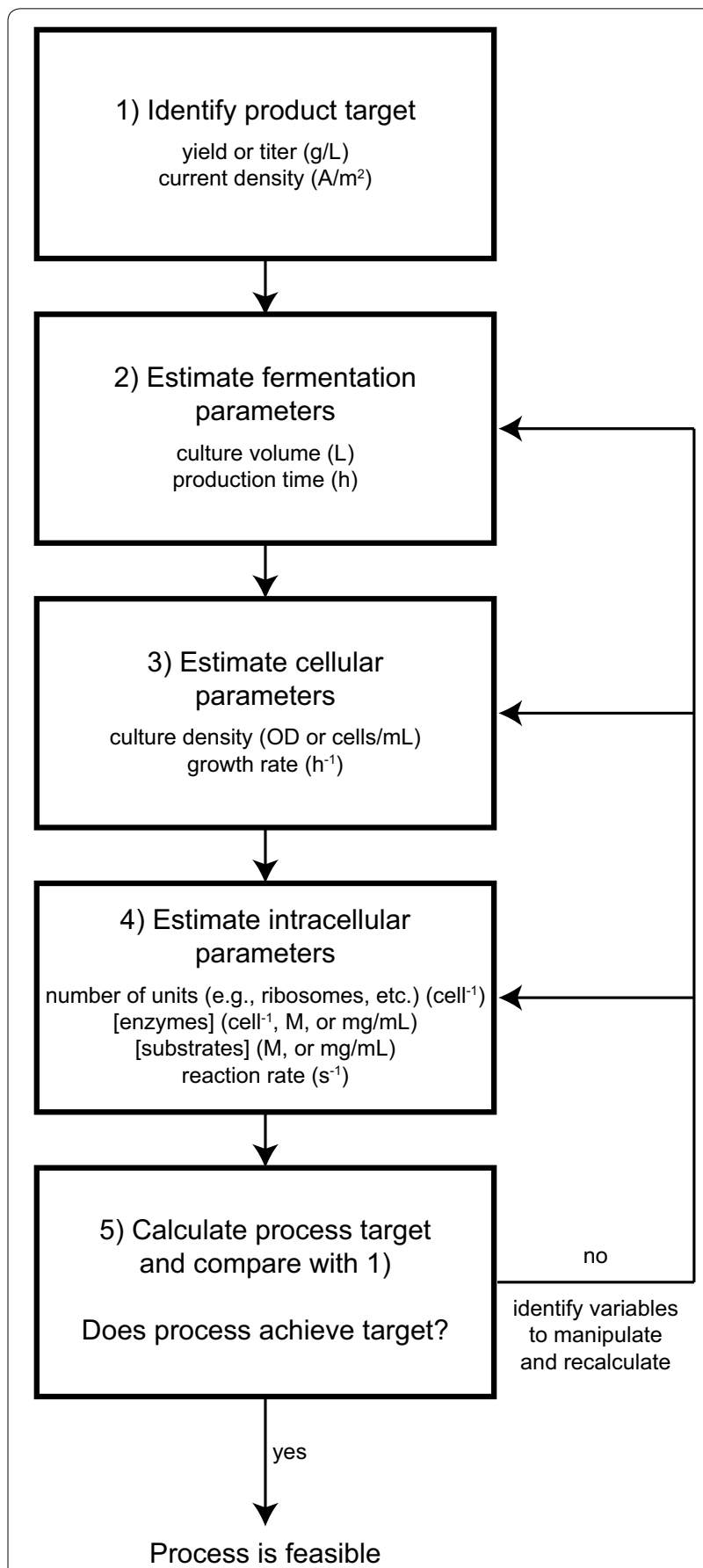

Fig. 4 Decision scheme for making rough estimates of process feasibility and variables to target for optimization. Estimates come from primary research, the BioNumbers database (http://bionumbers .hms.harvard.edu), and intuition

rough estimates in the literature alongside the project results. Given its importance, we strongly promote the inclusion of rough estimates in all future published work in the synthetic biology field. It will benefit new researchers learning to analyze new processes, as well as everyone interested in understanding the context of the work, including why certain parameters were not chosen for optimization.

\section{Abbreviations}

BNID: BioNumber identification number; DCW: dry cell weight; MCP: bacterial microcompartment.

\section{Authors' contributions}

All authors contributed in writing this review. All authors read and approved the final manuscript.

\section{Author details}

${ }^{1}$ Department of Chemical and Biomolecular Engineering, University of California, Berkeley, CA 94720, USA. ${ }^{2}$ Department of Chemical and Biological Engineering, Northwestern University, Evanston, IL 60208, USA. ${ }^{3}$ Present Address: Department of Biomedical Engineering, Northwestern University, Evanston, IL 60208, USA. ${ }^{4}$ Present Address: U.S. Army Edgewood Chemical Biological Center, Gunpowder, MD 21010, USA. ${ }^{5}$ Present Address: Department of Chemical and Systems Biology, Stanford University School of Medicine, Stanford, CA 94305, USA.

\section{Acknowledgements}

The authors would like to thank Shobhit Patoria and Michael Vincent for critical reading of the manuscript, as well as past and present members of the Tullman-Ercek group for stimulating discussions on the use of rough estimates in synthetic biology.

\section{Competing interests}

The authors declare that they have no competing interests.

\section{Availability of data and materials}

All data generated or analyzed during this study are included in this published article.

\section{Consent for publication \\ Not applicable.}

\section{Ethics approval and consent to participate} Not applicable.

\section{Funding}

This work was supported by the National Science Foundation (award MCB1 150567 to D.T.E. and a graduate research fellowship to K.J.M.), the Army Research Office (grant W911 NF-15-1-0144 to D.T.E.), and fellowships from the University of California (to K.J.M. and C.M.J.)

\section{Publisher's Note}

Springer Nature remains neutral with regard to jurisdictional claims in published maps and institutional affiliations.

Received: 29 May 2018 Accepted: 21 August 2018

Published online: 30 August 2018

\section{References}

1. Phillips R, Milo R. A feeling for the numbers in biology. Proc Natl Acad Sci. 2009;106:21465-71.

2. Milo R, Jorgensen P, Moran U, Weber G, Springer M. BioNumbers-the database of key numbers in molecular and cell biology. Nucleic Acids Res. 2010;38:D750-3.

3. Milo R, Phillips R. Cell biology by the numbers. 1st ed. New York: Garland Science; 2015

4. Ro D-K, Paradise EM, Ouellet M, Fisher KJ, Newman KL, Ndungu JM, et al. Production of the antimalarial drug precursor artemisinic acid in engineered yeast. Nature. 2006;440:940-3. 
5. Paddon CJ, Westfall PJ, Pitera DJ, Benjamin K, Fisher K, McPhee D, et al. High-level semi-synthetic production of the potent antimalarial artemisinin. Nature. 2013:496:528-32.

6. Fang X, Li J-X, Huang J-Q, Xiao Y-L, Zhang P, Chen X-Y. Systematic identification of functional residues of Artemisia annua amorpha-4,11-diene synthase. Biochem J. 2017;474:2191-202.

7. Han J, Wang H, Kanagarajan S, Hao M, Lundgren A, Brodelius PE. Promoting artemisinin biosynthesis in Artemisia annua plants by substrate channeling. Mol Plant. 2016:9:946-8.

8. Paddon CJ, Keasling JD. Semi-synthetic artemisinin: a model for the use of synthetic biology in pharmaceutical development. Nat Rev Microbiol. 2014;12:355-67.

9. Basson ME, Thorsness M, Rine J. Saccharomyces cerevisiae contains two functional genes encoding 3-hydroxy-3-methylglutaryl-coenzyme A reductase. Proc Natl Acad Sci U S A. 1986;83:5563-7.

10. Kazieva E, Yamamoto Y, Tajima Y, Yokoyama K, Katashkina J, Nishio Y. Characterization of feedback-resistant mevalonate kinases from the methanogenic archaeons Methanosaeta concilii and Methanocella paludicola. Microbiol Read Engl. 2017;163:1283-91.

11. Garcia DE, Keasling JD. Kinetics of phosphomevalonate kinase from Saccharomyces cerevisiae. PLoS ONE. 2014;9:e87112.

12. Krepkiy D, Miziorko HM. Identification of active site residues in mevalonate diphosphate decarboxylase: implications for a family of phosphotransferases. Protein Sci. 2004;13:1875-81.

13. Anderson MS, Muehlbacher M, Street IP, Proffitt J, Poulter CD. Isopentenyl diphosphate:dimethylallyl diphosphate isomerase. An improved purification of the enzyme and isolation of the gene from Saccharomyces cerevisiae. J Biol Chem. 1989;264:19169-75.

14. Teoh KH, Polichuk DR, Reed DW, Covello PS. Molecular cloning of an aldehyde dehydrogenase implicated in artemisinin biosynthesis in Artemisia annua. Botany. 2009;87:635-42.

15. Bar-Even A, Noor E, Savir Y, Liebermeister W, Davidi D, Tawfik DS, et al. The moderately efficient enzyme: evolutionary and physicochemical trends shaping enzyme parameters. Biochemistry. 2011;50:4402-10.

16. Chaudhuri SK, Lovley DR. Electricity generation by direct oxidation of glucose in mediatorless microbial fuel cells. Nat Biotechnol. 2003;21:1229-32

17. Finneran KT, Johnsen CV, Lovley DR. Rhodoferax ferrireducens sp. nov., a psychrotolerant, facultatively anaerobic bacterium that oxidizes acetate with the reduction of Fe(III). Int J Syst Evol Microbiol. 2003;53:669-73.

18. Jain R, Srivastava R. Metabolic investigation of host/pathogen interac tion using MS2-infected Escherichia coli. BMC Syst Biol. 2009;3:121.

19. Torella JP, Gagliardi CJ, Chen JS, Bediako DK, Colón B, Way JC, et al. Efficient solar-to-fuels production from a hybrid microbial-water-splitting catalyst system. Proc Natl Acad Sci. 2015;112:2337-42.

20. Liu C, Colón BC, Ziesack M, Silver PA, Nocera DG. Water splitting-biosynthetic system with $\mathrm{CO}_{2}$ reduction efficiencies exceeding photosynthesis. Science. 2016;352:1210-3.

21. Schein $\mathrm{CH}$. Production of soluble recombinant proteins in bacteria. Nat Biotechnol. 1989;7:1141-9.

22. Flamholz A, Phillips R, Milo R. The quantified cell. Mol Biol Cell. 2014:25:3497-500

23. Schlumberger MC, Müller AJ, Ehrbar K, Winnen B, Duss I, Stecher B, et al. Real-time imaging of type III secretion: Salmonella SipA injection into host cells. Proc Natl Acad Sci U S A. 2005;102:12548-53.

24. Singer HM, Erhardt M, Steiner AM, Zhang M-M, Yoshikami D, Bulaj G, et al. Selective purification of recombinant neuroactive peptides using the flagellar type III secretion system. MBio. 2012;3:e00115-12.

25. Kubori T, Matsushima Y, Nakamura D, Uralil J, Lara-Tejero M, Sukhan A, et al. Supramolecular Structure of the Salmonella typhimurium type III protein secretion system. Science. 1998;280:602-5.

26. Huang D, Gore PR, Shusta EV. Increasing yeast secretion of heterologous proteins by regulating expression rates and post-secretory loss. Biotechnol Bioeng. 2008;101:1264-75.

27. Li F, Vijayasankaran N, Shen A, Kiss R, Amanullah A. Cell culture processes for monoclonal antibody production. mAbs. 2010;2:466-77.

28. Reilly DE, Yansura DG. Production of monoclonal antibodies in E. coli. In: Shire S, Gombotz W, Bechtold-Peters K, Andya J, editors. Current trends in monoclonal antibody development and manufacturing.
Biotechnology: pharmaceutical aspects, vol XI. New York, NY: Springer; 2010. P. 295-308

29. Moran U, Phillips R, Milo R. SnapShot: key numbers in biology. Cell. 2010;141(1262-1262):e1.

30. Sturm A, Heinemann M, Arnoldini M, Benecke A, Ackermann M Benz $M$, et al. The cost of virulence: retarded growth of Salmonella typhimurium cells expressing type III secretion system 1. PLoS Pathog. 2011;7:e1002143.

31. Hautefort I, Proença MJ, Hinton JCD. Single-copy green fluorescent protein gene fusions allow accurate measurement of Salmonella gene expression in vitro and during infection of mammalian cells. Appl Environ Microbiol. 2003;69:7480-91.

32. Widmaier DM, Tullman-Ercek D, Mirsky EA, Hill R, Govindarajan S, Minshull J, et al. Engineering the Salmonella type III secretion system to export spider silk monomers. Mol Syst Biol. 2009;5:309.

33. Lee SY. High cell-density culture of Escherichia coli. Trends Biotechnol. 1996;14:98-105.

34. Metcalf KJ, Finnerty C, Azam A, Valdivia E, Tullman-Ercek D. Using transcriptional control to increase titers of secreted heterologous proteins by the type III secretion system. Appl Environ Microbiol. 2014;80:5927-34.

35. Azam A, Li C, Metcalf KJ, Tullman-Ercek D. Type III secretion as a generalizable strategy for the production of full-length biopolymer-forming proteins. Biotechnol Bioeng. 2016;113:2313-20.

36. Polka JK, Silver PA. Building synthetic cellular organization. Mol Biol Cell. 2013;24:3585-7.

37. Parsons JB, Frank S, Bhella D, Liang M, Prentice MB, Mulvihill DP, et al. Synthesis of empty bacterial microcompartments, directed organelle protein incorporation, and evidence of filament-associated organelle movement. Mol Cell. 2010;38:305-15.

38. Bobik TA, Havemann GD, Busch RJ, Williams DS, Aldrich HC. The Propanediol utilization (pdu) operon of Salmonella enterica serovar typhimurium LT2 includes genes necessary for formation of polyhedral organelles involved in coenzyme B12-dependent 1,2-Propanediol degradation. J Bacteriol. 1999:181:5967-75.

39. Lechner A, Brunk E, Keasling JD. The need for integrated approaches in metabolic engineering. Cold Spring Harb Perspect Biol. 2016:8:a023903.

40. Shanmugam KT, Ingram LO. Engineering biocatalysts for production of commodity chemicals. J Mol Microbiol Biotechnol. 2008;15:8-15.

41. Subedi KP, Kim I, Kim J, Min B, Park C. Role of GIdA in dihydroxyacetone and methylglyoxal metabolism of Escherichia coli K12. FEMS Microbiol Lett. 2008;279:180-7.

42. Saadat $\mathrm{D}$, Harrison $\mathrm{DH}$. Identification of catalytic bases in the active site of Escherichia coli methylglyoxal synthase: cloning, expression, and functional characterization of conserved aspartic acid residues. Biochemistry. 1998;37:10074-86

43. Ko J, Kim I, Yoo S, Min B, Kim K, Park C. Conversion of methylglyoxal to acetol by Escherichia coli aldo-keto reductases. J Bacteriol. 2005; 187:5782-9.

44. Chazan A. Peptide properties calculator. http://biotools.nubic.north western.edu/proteincalc.html. Accessed 8 Aug 2018.

45. Jakobson CM, Tullman-Ercek D, Slininger MF, Mangan NM. A systemslevel model reveals that 1,2-Propanediol utilization microcompartments enhance pathway flux through intermediate sequestration. PLoS Comput Biol. 2017;13:e1005525.

46. Kim EY, Jakobson CM, Tullman-Ercek D. Engineering transcriptional regulation to control Pdu microcompartment formation. PLoS ONE. 2014;9:e113814.

47. Slininger Lee MF, Jakobson CM, Tullman-Ercek D. Evidence for improved encapsulated pathway behavior in a bacterial microcompartment through shell protein engineering. ACS Synth Biol. 2017;6:1880-91.

48. Jakobson CM, Kim EY, Slininger MF, Chien A, Tullman-Ercek D. Localization of proteins to the 1,2-Propanediol utilization microcompartment by non-native signal sequences is mediated by a common hydrophobic motif. J Biol Chem. 2015;290:24519-33.

49. Jakobson CM, Chen Y, Slininger MF, Valdivia E, Kim EY, Tullman-Ercek D. Tuning the catalytic activity of subcellular nanoreactors. J Mol Biol. 2016;428:2989-96. 